\title{
Co-culture of Platelets with Monocytes Induced M2 Macrophage Polarization and Formation of Foam Cells: Shedding Light on the Crucial Role of Platelets in Monocyte Differentiation
}

\author{
Trombositlerin Monositlerle Ortak Kültürü ile Indüklenen M2 Makrofaj Polarizasyonu ve Köpük \\ Hücrelerinin Oluşumu: Monosit Farkıllaşmasında Trombositlerin Önemli Rolü Üzerine Işık Tutma
}

\author{
(D) Mahdieh Mehrpouri1, (D) Davood Bashash1, (D) Mohammad Hossien Mohammadi2, (D) Mohammad Esmail Gheydari3, \\ (D) Esmail Shahabi Satlsar ${ }^{1}$, (D) Mohsen Hamidpour2
}

1Shahid Beheshti University of Medical Sciences, Faculty of Allied Medical Sciences, Department of Hematology and Blood Banking, Tehran, Iran 2HSCT Research Centre, Department of Hematology and Blood Banking, School of Allied Medical Sciences, Shahid Beheshti University of Medical Sciences, Tehran, Iran

${ }^{3}$ Shahid Beheshti University of Medical Sciences Faculty of Medicine, Taleghani General Hospital, Department of Cardiology, Tehran, Iran

\section{Abstract}

Objective: Far beyond hemostasis and thrombosis, significant evidence has indicated the critical role of platelets in atherosclerosis. SDF-1 is among the pro-inflammatory chemokines that are increased in platelets of patients with coronary artery disease (CAD). The goal of the current work is to identify the in vitro effect of platelets from either CAD patients or healthy volunteers on the induction of macrophages and foam cells.

Materials and Methods: The expression of SDF-1 on platelet surfaces in $C A D$ patients and healthy volunteers was investigated using flow cytometry. We also evaluated the CXCR4/CXCR7 expression on monocytes from buffy coats of healthy volunteers. The effect of platelets from CAD patients and healthy volunteers on differentiation of monocytes and foam cell formation was evaluated using Oil Red 0 (ORO) staining. Flow cytometry and real-time PCR were also employed to evaluate surface markers and mRNA expression of genes involved in this process after co-culture of platelets with monocytes.

Results: Monocytes in co-culture with platelets acquired a spindleshape appearance and ORO-positive lipid droplets. In addition, platelets could induce CD163 expression, as an important marker of $\mathrm{M} 2$ macrophage, and upregulate the mRNA expression of the $S R B, C D 36, A C A T, L X R-\alpha$, and ABCA1 genes in monocytes. Notably, platelets of CAD patients with higher expression of SDF-1, increased the expression of genes encoding SRB and CD36 as compared to platelets of healthy volunteers.

Conclusion: Our results indicate that platelets from CAD patients could provoke monocyte differentiation into macrophages with an M2 phenotype, which in turn may participate in an atheroprotective process.

Keywords: SDF-1, Monocytes, Platelets, Co-culture, Foam cells
Öz

Amaç: Hemostaz ve trombozun çok ötesinde, önemli kanıtlar trombositlerin aterosklerozdaki kritik rolüne işaret etmektedir. SDF-1 koroner arter hastalığı (KAH) olan hastaların trombositlerinde artan proenflamatuvar kemokinler arasında yer almaktadır. Bu çalışmanın amacı, $\mathrm{KAH}$ olan hastalar ve sağlıklı gönüllülerin trombositlerinin makrofajlar ve köpük hücrelerinin indüksiyonunda in vitro etkilerini belirlemektir.

Gereç ve Yöntemler: KAH olan hastalar ve sağlıklı gönüllülerde trombosit yüzeyindeki SDF-1 ekspresyonu akım sitometri ile incelendi. Biz ayrıca sağlıklı gönüllülerin beyaz kan hücrelerinin bir tabakasından elde edilen monositlerde CXCR4/CXCR7 ekspresyonunu değerlendirdik. $\mathrm{KAH}$ olan hastalar ve sağlıklı gönüllülerin trombositlerinin monositler ve köpük hücreleri oluşumu üzerine etkisi Oil Red 0 (ORO) boyası kullanılarak değerlendirildi. Yüzey belirteçlerini ve trombositlerin monositlerle ortak kültürü sonrası süreçteki genlerin mRNA ekspresyonunu değerlendirmek için ayrıca akım sitometri ve gerçek zamanlı polimeraz zincir reaksiyonu çalışıldı.

Bulgular: Trombositler ile ortak kültüre edilen monositler iğ şeklinde görünüm ve ORO-pozitif yağ damlacıkları kazandılar. Ayrıca, trombositler M2 makrofajın önemli bir belirteçi olan CD163 ekspresyonunu indüklediler ve monositlerdeki $S R B, C D 36, A C A T$, $L X R-\alpha$, ve $A B C A 1$ genlerinin mRNA ekspresyonunu up-regüle ettiler. Özellikle, SDF-1 ekspresyonu yüksek olan KAH olan hastaların trombositleri, sağlıklı gönüllülere göre SRB ve CD36'yı kodlayan genlerin ekspresyonunu artırdı.

Sonuç: Bulgularımız, KAH olan hastaların trombositlerinin, monositlerin M2 fenotipinde makrofajlara farklılaşmasına neden olduklarını ve böylece ateroprotektif sürece iştirak ettiklerini göstermektedir.

Anahtar Sözcükler: SDF-1, Monositler, Trombositler, Ortak kültür, Köpük hücreleri

๑Copyright 2019 by Turkish Society of Hematology

Turkish Journal of Hematology, Published by Galenos Publishing House

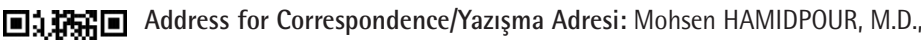

31 Shahid Beheshti University of Medical Sciences, Hematopoietic Stem Cells Research Centre, Tehran, Iran

E-mail : mohsenhp@sbmu.ac.ir ORCID-ID: orcid.org/0000-0002-3658-1551

Received/Geliş tarihi: December 30, 2018 Accepted/Kabul tarihi: March 08, 2019 


\section{Introduction}

Atherosclerosis is a multifactorial process that leads to cardiovascular diseases and involves a complex interaction between cellular and non-cellular constituents, which include platelets, cytokines, and leukocytes [1]. Far beyond hemostasis and thrombosis, the critical role of platelets in wound healing, inflammation, atherosclerosis, and the immunity system has been recognized $[2,3]$. Platelets store a wide variety of cytokines, chemokines, mitogens, angiogenic factors, and other bioactive molecules in their granules $[4,5]$, which can potentially induce pro- and anti-inflammatory responses [6]. Several investigations have reported the crucial role of chemokines in the pathogenesis of cardiovascular diseases [7]. SDF-1 (CXCL12) is among the pro-inflammatory chemokines released following platelet activation $[8,9]$. Circulating platelets of patients with coronary artery disease (CAD) have elevated expression of SDF-1 $[10,11]$, which is associated with cardio-protection and enhanced left ventricular functional recovery after myocardial infarction $[12,13]$. At injury sites, platelets recruit and activate leukocytes through cell-cell interactions or indirectly by release of their mediators [14]. Remarkably, platelet-derived SDF-1 can bind to its chemokine receptors, CXCR4 and CXCR7, on monocytes and facilitate phagocytosis of apoptotic platelets by these cells and promote their differentiation into foam cells [15].

Classically, macrophages are classified into two major subtypes: pro-inflammatory M1 macrophages and anti-inflammatory M2 macrophages [16]. Briefly, M1 macrophages sustain the inflammatory response through production of inflammatory cytokines. On the other hand, M2 macrophages contribute to wound repair and tissue regeneration [17]. According to the expression of surface markers, CD86 is used as an M1 macrophage marker [18], while CD163 is commonly used to detect M2 macrophages [19].

We hypothesized that increased expression of SDF-1 on the platelets of CAD patients will promote differentiation of monocytes into macrophages or foam cells. Therefore, the aim of this study was to investigate the in vitro effect of $C A D$ patients' platelets in induction of macrophage and foam cells in comparison with normal platelets.

\section{Materials and Methods}

\section{Materials}

Mouse monoclonal anti-human CD61-FITC (Dako, Denmark), mouse monoclonal anti-human CXCR4-PE (BioLegend, USA), mouse monoclonal anti-human/mouse CXCR7-PE (BioLegend, USA), mouse monoclonal anti-human SDF-1-PerCP (Novus Biologicals, USA), mouse monoclonal anti-human CD14-PE (Beckman Coulter, USA), mouse monoclonal anti-human CD11bPE (Dako, Denmark), mouse monoclonal anti-human CD11c-FITC
(Dako, Denmark), mouse monoclonal anti-human CD86-PerCP (Abcam, USA), and mouse monoclonal anti-human CD163-FITC (R\&D Systems, UK) were used in our study. Ficoll-Hypaque was from Lymphodex (Inno-Train, Germany), Taq DNA Polymerase 2x Master Mix RED and Real 0 Plus Master Mix Green Low ROX were procured from Ampliqon (Copenhagen, Denmark), the RevertAid First Strand cDNA Synthesis Kit was from Thermo Fisher Scientific (USA), and trypan blue, Oil Red 0 (ORO) stain, and TRIzol were purchased from Sigma-Aldrich (USA).

\section{Expression of SDF-1 on Platelets of CAD Patients and Healthy Volunteers}

Ten patients with symptomatic CAD who were visited in the cardiovascular section of Taleghani Hospital (Tehran) were investigated for SDF-1 expression on the surface of platelets. CAD patients were selected with respect to clinical symptoms, myocardial ischemia markers, and ECG results. The increased level of SDF-1 was an inclusion criterion for selection of CAD patients for evaluation in co-culture, while exclusion criteria were diabetes, history of CAD in the family, hypertension, hyperlipidemia, smoking, and medication usage on admission. Ten healthy volunteers with no history of cardiovascular diseases, who were matched with the CAD patients regarding age and sex ( $p>0.05)$, were also evaluated as normal controls. Finally, three patients with high expression of this marker were selected for platelet preparation in comparison with three healthy volunteers with low expressions of SDF-1. This study was approved by the Ethics Committee of Shahid Beheshti University of Medical Sciences (IR.SBMU.RETECH. REC.1396.717) and all the participants gave informed consent in accordance with the Declaration of Helsinki. To detect the surface expression of SDF-1, diluted platelet-rich plasma (PRP) was incubated with mouse monoclonal anti-human SDF-1-PerCP and mouse monoclonal anti-human CD61-FITC or their respective isotype controls and analyzed by flow cytometer (Attune NxT; Life Technologies, USA). Platelet CD61 expression was used in the present study for identifying the platelet population. We also used mean fluorescence intensity (MFI) as a quantitative indicator for the surface expression of the indicated protein.

\section{Isolation of Platelets}

Peripheral blood was collected in ACD-A (Acid Citrate Dextrose, solution-A) anticoagulant (1:4) from CAD patients and healthy volunteers and centrifuged at $200 \mathrm{~g}$ for $15 \mathrm{~min}$. The prepared PRP was added to Tyrode's HEPES buffer (HEPES - $2.5 \mathrm{mM}, \mathrm{NaCl}$ - $150 \mathrm{mM}, \mathrm{KCl}-1 \mathrm{mM}, \mathrm{NaHCO}_{3}-2.5 \mathrm{mM}, \mathrm{NaH}_{2} \mathrm{PO}_{4}-0.36 \mathrm{mM}$, glucose - $5.5 \mathrm{mM}, \mathrm{BSA}-1 \mathrm{mg} / \mathrm{mL}, \mathrm{pH} 6.5$ ) and centrifuged at $800 \times \mathrm{g}$ for $10 \mathrm{~min}$. The platelet pellet was suspended in Tyrode's HEPES buffer ( $\mathrm{pH}$ 7.4; supplemented with $\mathrm{CaCl}_{2}-1 \mathrm{mM}, \mathrm{MgCl}_{2}$ $-1 \mathrm{mM})$. 


\section{Peripheral Blood Monocyte Preparation}

Buffy coats from healthy volunteers were used for isolation of peripheral blood monocytes. Subsequently, we purified monocytes through centrifugation on a Ficoll-Hypaque density gradient $(20 \mathrm{~min}, 760 \times \mathrm{g}$ ) and adhesion to a plastic surface. Non-adherent cells were removed by gentle washing after $4 \mathrm{~h}$ and the remaining adherent cells (monocytes) were harvested. Viability of monocytes, as measured by trypan blue dye exclusion, was $>98 \%$ immediately after their isolation. Monocyte purity was assessed using flow cytometry analysis of FSC-SSC and surface CD14 expression. The expressions of CXCR4 and CXCR7 on monocytes were also evaluated by flow cytometry.

\section{Monocyte and Platelet Co-culture}

Monocytes were grown in RPMI-1640 medium supplemented with $100 \mathrm{U} / \mathrm{mL}$ penicillin, $100 \mu \mathrm{g} / \mathrm{mL}$ streptomycin, $2 \mathrm{mM}$ L-glutamine, and $10 \%$ fetal calf serum in a humidified atmosphere of $5 \% \mathrm{CO}_{2}$ at $37{ }^{\circ} \mathrm{C}$. Isolated platelets were added to monocytes (monocyte to platelet ratio of 1:100), and half of the medium was exchanged with fresh complete medium every 2 days. During co-culture, monocytes were examined by microscopic analysis. After co-culture, platelets or floating cells were washed away and monocytes were evaluated by ORO staining, flow cytometry, and real-time PCR.

\section{ORO Staining for Foam Cell Evaluation}

For ORO staining, the cells were stained after 7,10 , and 15 days of co-culture. After 2-3 washings with PBS, 10\% formalin was used to fix the cells for $30 \mathrm{~min}$, and then they were penetrated with 60\% isopropanol for $5 \mathrm{~min}$ and stained with ORO staining for $10 \mathrm{~min}$ at room temperature. To remove any residual ORO stain, 60\% isopropanol was used to destain wells for $15 \mathrm{~s}$, and next the wells were washed 3 times with PBS. Images of foam cells were taken under 10x and $40^{\mathrm{x}}$ objectives by light microscope (Olympus) with an Optika camera (Italy). Image analysis was performed using ImageJ software.

\section{Flow Cytometry Assessment of Monocytes}

Surface expressions of markers on differentiated macrophages were analyzed using flow cytometry following 7 days of coculture. PBS was used to wash the cells, and with fluorescentconjugated antibodies against CD14, CD11b, CD11 c, CD86, and CD163 or their respective isotype controls, cells were labeled. After 30 min of incubation in the dark at $4{ }^{\circ} \mathrm{C}$, cells were then fixed with $0.5 \%$ paraformaldehyde and were measured using flow cytometry. Analysis of data was performed by gating on viable cells using FSC-SSC characteristics in the monocyte/ macrophage population. The percentage of each marker was determined against its respective isotype control.

\section{cDNA Synthesis}

Total RNA was isolated from harvested monocytes following 7 days of co-culture with TRIzol according to the manufacturer's recommendation and converted to complementary DNA (cDNA) using a cDNA synthesis kit. Quantitative real-time PCR for $A B C A 1, C D 36, S R B, P P A R \gamma, S R A, A C A T 1, A B C G 1$, and $L X R-\alpha$ (NR1H3) was carried out with a Rotor Gene 0 kit (OIAGEN, Germany) using Real-Time PCR Master Mix. The housekeeping gene $A B L$ was also used as a control for differences in RNA concentrations. All the primers that were used in our research are given in Table 1.

\section{Statistical Analysis}

Each experimental condition was performed in triplicate to evaluate the mean \pm standard deviation (SD). All data were analyzed using Prism software (USA). To determine the difference between two groups, the unpaired two-tailed Student t-test was applied. ANOVA was applied to compare multiple data. In all cases, the minimum statistical significance was $p<0.05$.

\section{Results}

\section{Platelets of Patients with CAD Had Increased Expression of SDF-1}

As shown in Figure 1, analysis of flow cytometry data showed that the expression of SDF-1 on the platelets of CAD patients

\begin{tabular}{|c|c|c|c|}
\hline Gene & Forward primer $\left(5^{\prime}-3^{\prime}\right)$ & Reverse primer $\left(5^{\prime}-3^{\prime}\right)$ & Product size (bp) \\
\hline$A B C A 1$ & GGCAATCATCAGGGTGCTGACG & CCGCAGAAAGATGTCATCAACG & 97 \\
\hline CD36 & GCAGCAACATCAAGTTAAGC & AGCCTCTGTCCAACTGATAG & 158 \\
\hline SRB & ПТGCCAACGGGTCCATCTAC & CAGTTGTCCAATGCCTGCG & 288 \\
\hline PPARY & АПTCTCAGTGGAGACCGCCC & GGAAATGTTGGCAGTGGCTC & 292 \\
\hline SRA & CACTGATGCCCTTACCTCCTC & САПTССTCПТGСTGTCAПTСC & 170 \\
\hline ACAT & TCTACTCCATGTACCACCATAAAC & CATAAGCGTCCTGTCAПTCG & 298 \\
\hline$A B C G 1$ & TAGATAATAACCTCACGGAAGC & CСАССААСТСАССАСТАТТG & 177 \\
\hline $\mathrm{NR} 1 \mathrm{H} 3$ & ACAACCCTGGGAGTGAGAGT & AACATCAGTCGGTCATGGGG & 295 \\
\hline$A B L 1$ & стतCTGGTGCGTGAGAGTGAG & GACGTAGAGCTGCCATCAGAAG & 115 \\
\hline
\end{tabular}



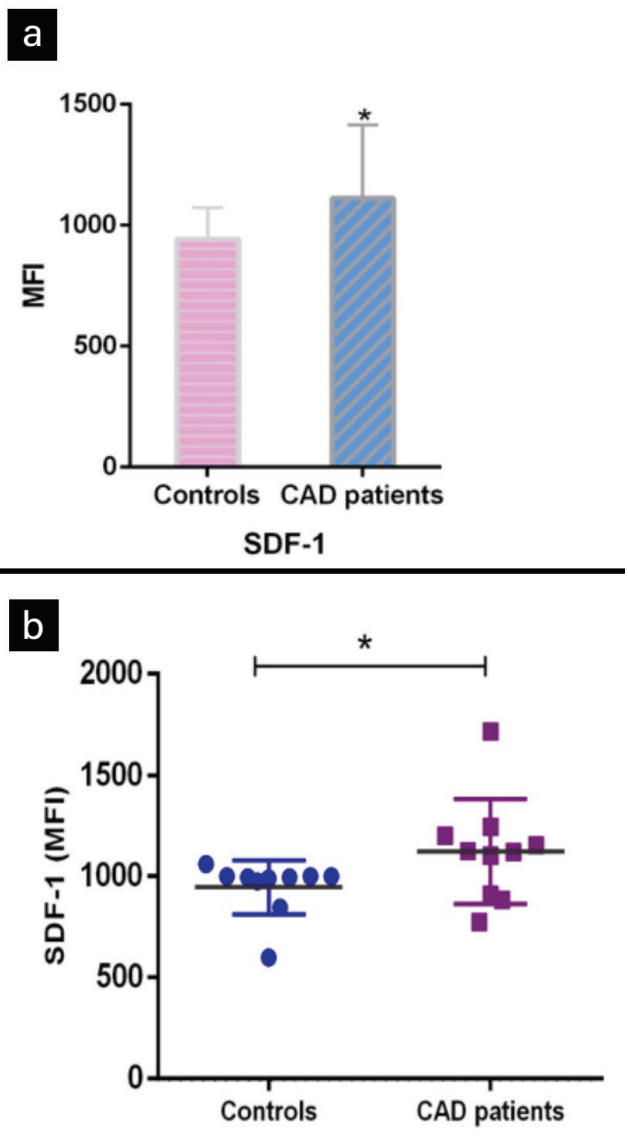

Figure 1. Assessment of the expression of SDF-1 on the platelets of ten healthy volunteers and ten patients with symptomatic coronary artery disease (CAD). (a) Platelet SDF-1 expression was significantly higher in $C A D$ patients than in the healthy controls. (b) Comparison of the expression of SDF-1 on the platelets of controls and CAD patients. Statistical values are given as mean \pm standard deviation. ${ }^{*} p<0.05$.

MFI: Mean fluorescence intensity. was significantly higher than that of healthy controls (MFI: $1112 \pm 304$ vs. $943 \pm 131, p=0.042$ ).

\section{Surface Expression of CXCR4 and CXCR7 on Monocytes}

We evaluated the expression of CXCR4 and CXCR7 on surface of monocytes which were isolated from buffy coats on the first day. Our results showed that the expression levels of CXCR4 and CXCR7 on monocytes were $51.7 \pm 3.2 \%$ and $28.5 \pm 2.5 \%$, respectively (Figure 2).

\section{Platelets Significantly Induced Spindle-Shape Appearance in Macrophages}

In vitro and in vivo maturation of blood monocytes into macrophages takes place as a consequence of interactions with different cell types. We evaluated monocyte morphology for 20 days of co-culture and we showed that monocyte-platelet coculture prompted platelet clearance. Moreover, platelets induced differentiation of monocytes into macrophages with spindleshaped appearance. After prolonged co-culture (15 days), a considerable proportion of these cells showed morphological characters of foam cells. Furthermore, our results indicated that platelets of CAD patients had enhanced differentiation of monocytes to foam cells in comparison with platelets of healthy volunteers (Figure 3).

\section{ORO Staining Showed Significant ORO-Stained Lipid Droplets in Monocytes}

Formation of foam cells is time-dependent, so we stained and analyzed ORO-stained lipid droplets on days 7, 10, and 15 following co-culture of monocytes and platelets. After 7 days, macrophages showed no significant ORO-stained lipid droplets, but after prolonged co-culture to 10 and 15 days, lipid droplets were seen more significantly in macrophages cultured with a

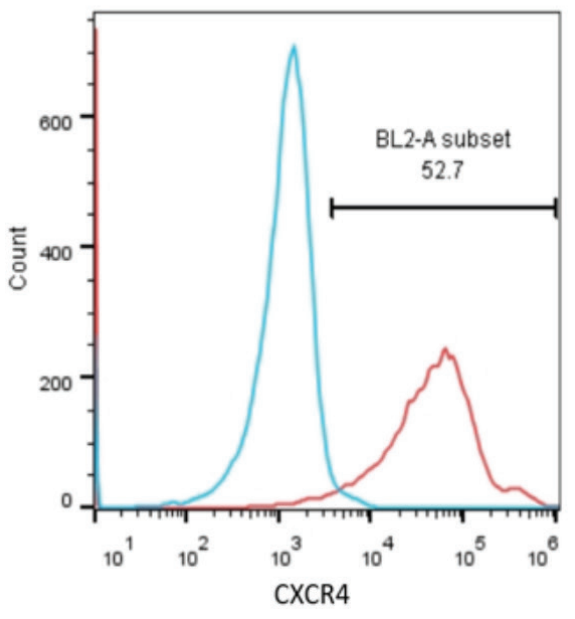

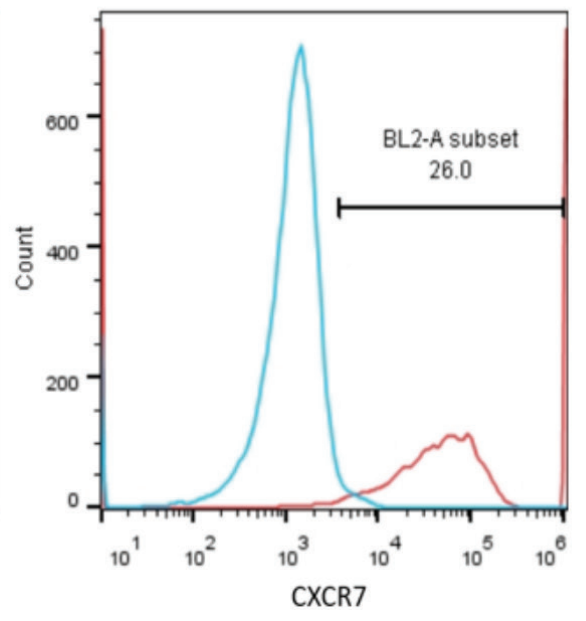

b

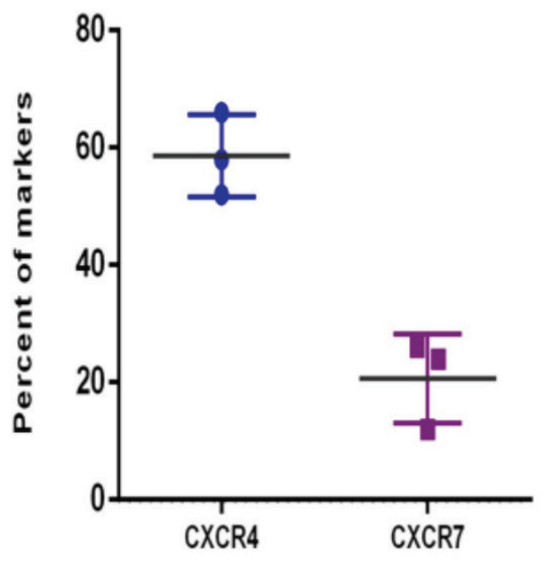

Figure 2. Flow cytometry analysis of CXCR4 and CXCR7 on monocytes isolated from buffy coats. (a) Histograms show that monocytes isolated from buffy coats expressed CXCR4 and CXCR7 with respect to corresponding isotype controls. (b) Comparison of expression of CXCR4 and CXCR7 on monocytes isolated from buffy coats. Experiments were conducted in triplicate. 
platelets. Furthermore, ORO staining indicated that platelets of CAD patients had enhanced differentiation of monocytes into foam cells in comparison with platelets of healthy volunteers (Figure 4).

\section{Platelets Increased CD163 Expression on Monocytes After 7 Days}

Monocytes express CD163 at low to moderate levels [20]; however, alternatively activated macrophages have high expressions of this marker. These cells play an important role in inhibiting the inflammatory responses and scavenging components of damaged cells [21]. Flow cytometry was conducted to detect the surface expression of monocyte markers following isolation. As shown in Figure 5a, monocyte purity, which was investigated using FSC-SSC and CD14 expression, was above 98\%. Expression of other markers was analyzed on day 1 and high expressions of CD11b and CD11c and low expressions of CD163 and CD86 were identified. In monocytes on day 7, whether cultured in the presence of platelets or without platelets, high expressions of CD14, CD11b, and CD11c were detected (Figure 5b). CD86 expression on monocytes was associated with a decrease after 7 days of co-culture, independent of the presence or absence of platelets. A slightly increased expression of CD163 was observed in platelet-free cultures on day 7 compared with day 1 . However, a significant increase of this marker was detected on monocytes co-cultured with platelets (Figure 5c).

\section{Platelets Induced the Expression of the Genes Involved in Cholesterol Absorption, Cholesterol Esterification, and Cholesterol Efflux in Monocytes}

In this study, following co-culture of monocytes with platelets, we investigated the mRNA expression of $C D 36$, scavenger receptor class A $(S R A)$, and acyl-coenzyme A cholesterol acyltransferase (ACAT) in monocytes, which are among the key genes in lipid accumulation [22,23]. We also evaluated the gene expression changes that are expected to enhance the cholesterol efflux from foam cells, including ATP-binding cassette transporter A1 (ABCA1), ATP-binding cassette transporter G1 (ABCG1), peroxisome proliferator-activated receptor $\gamma$ (PPAR $\gamma$ ), liver $X$ receptor- $\alpha(L X R-\alpha)$, and scavenger receptor class $B$ (SRB) $[24,25,26]$. Our results showed that platelets elevated the expression of mRNA of CD36, ACAT, ABCA1, SRB, and $L X R-\alpha$.
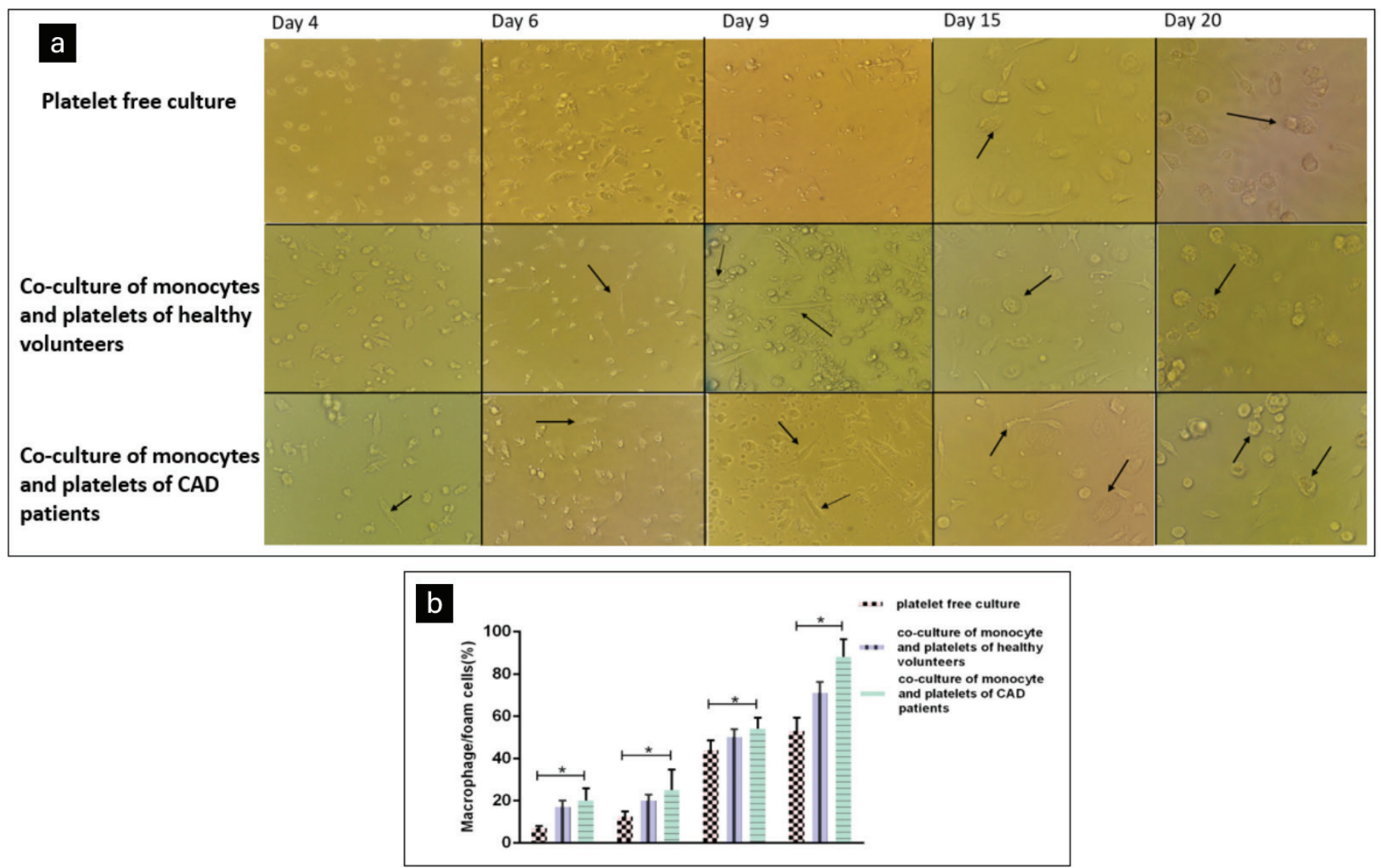

Figure 3. Assessment of changes in monocyte morphology at different days of culture. (a) Platelets helped monocytes differentiate into macrophages and foam cells as compared to platelet-free culture. Furthermore, platelets of coronary artery disease (CAD) patients had more monocytes differentiated into foam cells in comparison with platelets of healthy volunteers. Monocyte shape changed following co-culture with platelets as shown with arrows in the pictures. Magnification: 400x. (b) Bar diagram representing a comparison of monocyte shape changes on different days of cultures. Experiments were conducted in triplicate. 
Furthermore, platelets of CAD patients had significantly elevated mRNA expression of $C D 36$ and $S R B$ in comparison with platelets of healthy volunteers, which indicated that these platelets play a larger role in the formation of macrophage and foam cells (Figure 6).

\section{Discussion}

Platelets are important players in atherosclerosis and recruit other cells towards lesion sites [27]. Alpha-granules of platelets are major sources of SDF-1, a well-known chemokine that is overexpressed on the surface of platelets upon activation [28]. Notably, it has been reported that among leukocyte subtypes, monocytes preferentially interact with activated platelets through CXCR4 and CXCR7 [15]. According to studies, CD163 expression, as an important marker of M2 macrophages, is elevated in macrophages of inflamed tissues like atherosclerotic lesions [29]. Moreover, Buchacher et al. [30] indicated that monocytes with spindle-shape morphology are mainly representative of M2 macrophages. In this study, we evaluated the interaction of monocytes and platelets for 20 days. We showed that over 7 days platelets not only drive the monocytes to differentiate into spindle-shape macrophages, but also upregulate the expression of CD163, which is in agreement with a recent study conducted by Chatterjee et al. [15]. Our results also revealed that longer co-culture of cells resulted in a considerable proportion of macrophages presenting morphological characteristics of foam cells. Platelets of CAD patients that expressed a higher percentage of SDF-1 induced greater numbers of foam cells as compared to platelets of healthy volunteers, indicating that SDF-1 derived from platelets may play a probable role in differentiation of monocytes to foam cells.

Although previous studies discussed the contributory role of platelets in the differentiation of monocytes into foam cells [9],
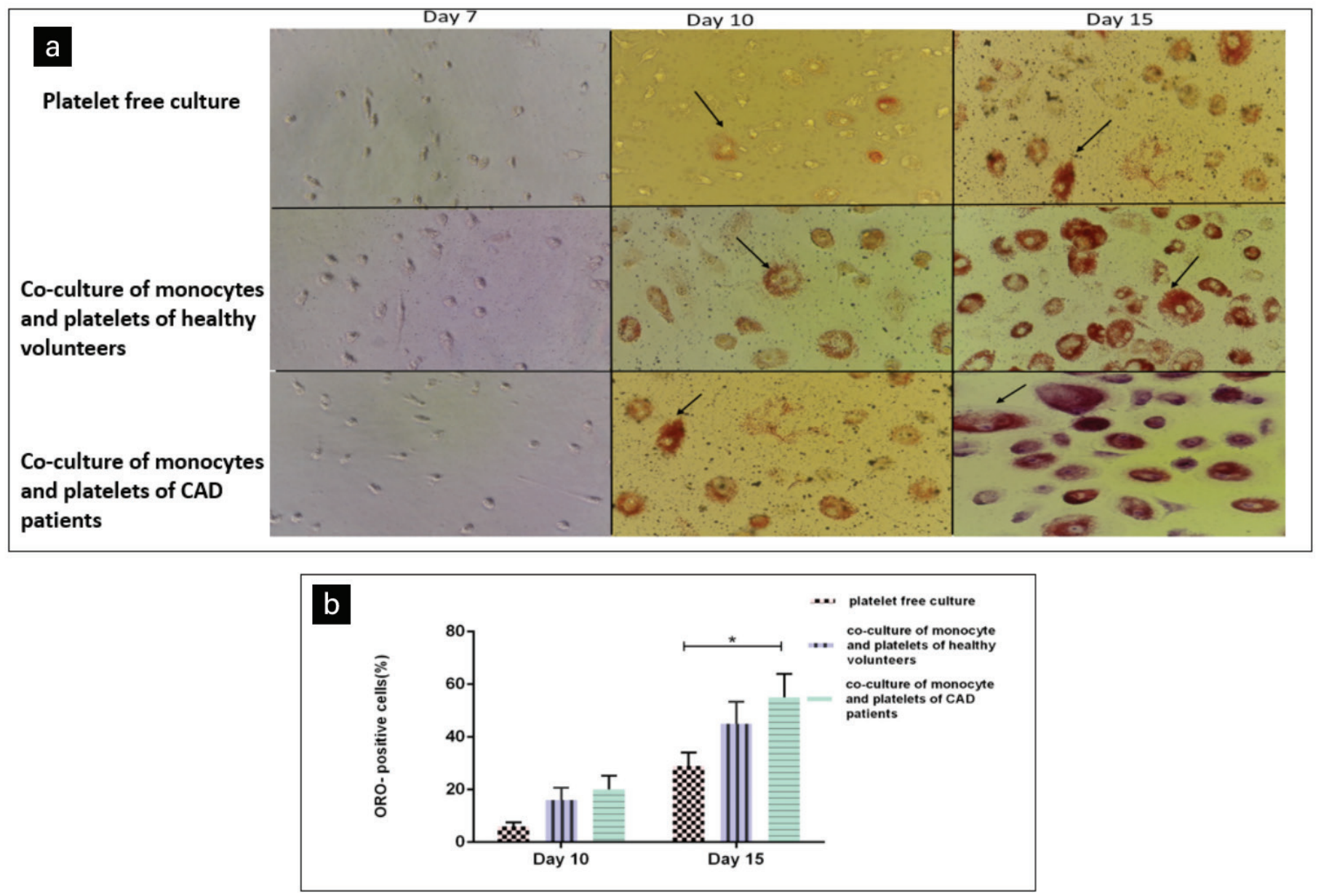

Figure 4. Evaluation of macrophage foam cells using Oil Red 0 (ORO) staining during different days of co-culture. (a) After 7 days, macrophages showed no significant ORO-stained lipid droplets, although after 10 and 15 days of co-culture, significantly more lipid droplets with ORO staining could be observed in foam cells cultured with platelets. Furthermore, ORO staining indicated that platelets of coronary artery disease patients had enhanced differentiation of monocytes to foam cells in comparison with platelets of healthy volunteers. Foam cells are shown with arrows in the picture. Magnification: 400x. (b) Bar diagram representing a comparison of OROpositive cells between different samples on days 10 and 15. Each experiment was conducted in triplicate.

CAD: Coronary artery disease. 


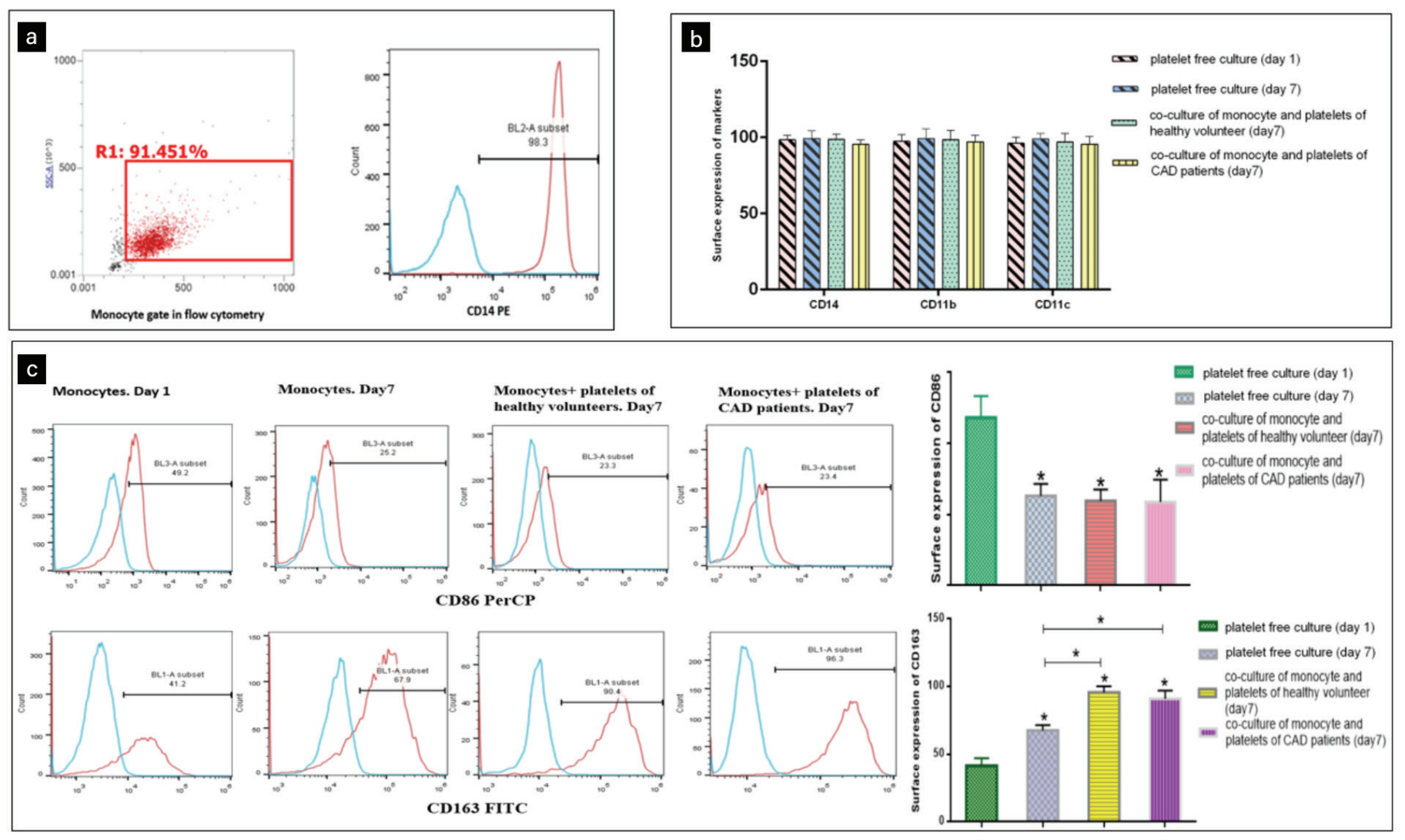

Figure 5. Platelets in co-culture induced monocytes to differentiate into CD163-positive macrophages. (a) Flow cytometry measurement of CD14 expression was used to assess the purity of isolated monocytes. (b) Bar graph represents phenotypes of monocytes in terms of CD14, CD11b, and CD11c surface expression in co-culture with platelets compared with platelet-free cultures. (c) Flow cytometry data represent CD86 and CD163 expressions of monocytes. Flow cytometric histograms of CD86 and CD163 expression showed substantial expression of CD163 as compared to the corresponding isotype controls on monocytes in co-culture with platelets. Representative flow cytometric bar diagrams of CD86/CD163 expression on monocytes show predominant CD163 expression of monocytes in co-culture with platelets compared with platelet-free cultures. CD86 expression of monocytes was associated with a decrease after 7 days of culture.

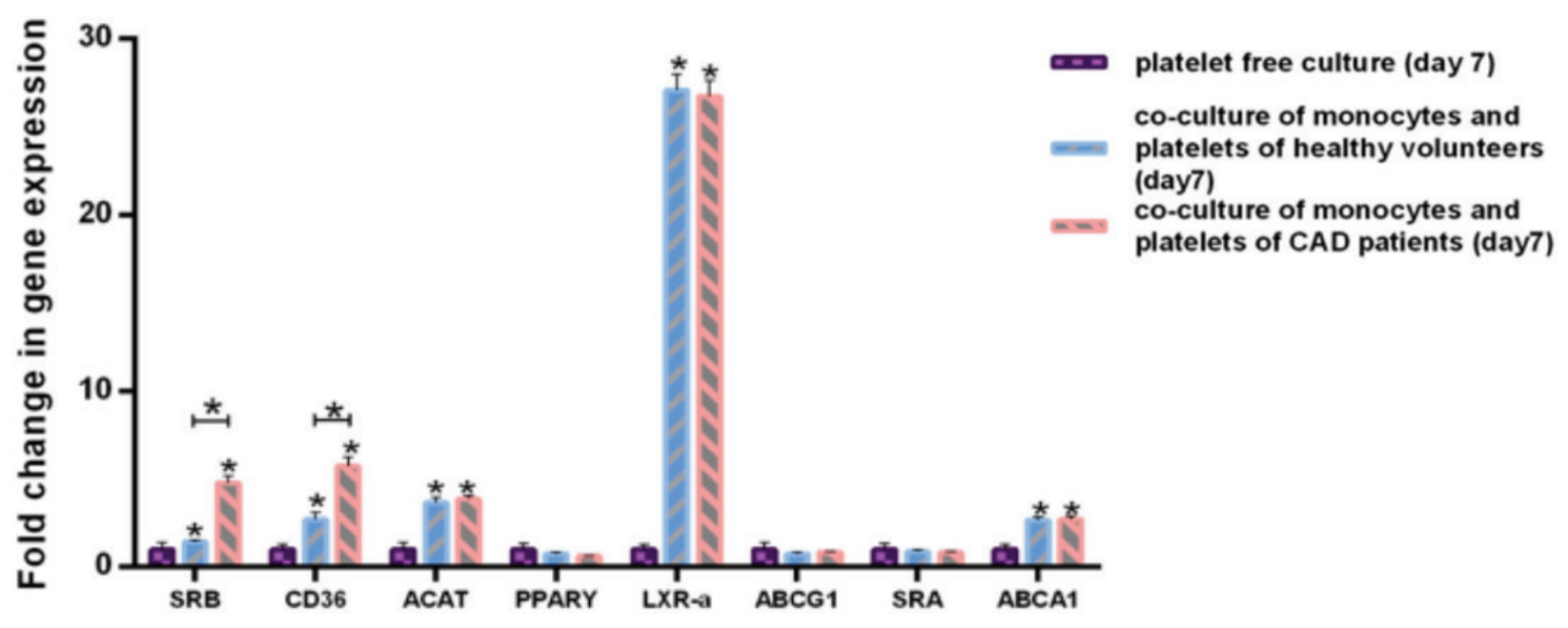

Figure 6. Evaluation of gene expression changes of monocytes after 7 days. After co-culture of monocytes with platelets of healthy volunteers, quantitative reverse transcription-polymerase chain reaction analysis demonstrated the increased expression of the following genes: SRB, CD36, $A C A T, L X R-\alpha$, and ABCA1. Co-culture of monocytes with platelets of CAD patients had the same results, but compared to platelets of healthy volunteers, increased expression of CD36 and SRB was observed. Statistical values are given as the mean \pm standard deviation of 3 independent experiments. ${ }^{*} \mathrm{p} \leq 0.05$. 
the precise molecular mechanisms of this effect were poorly understood. To the best of our knowledge, this is the first time that the expression levels of genes that are mainly involved in the conversion of monocytes-macrophages into foam cells were evaluated after co-culture of platelets with monocytes. Our findings demonstrated that platelets increased the mRNA expression of the CD36, $A C A T, S R B, L X R-\alpha$, and $A B C A 1$ genes. The role of these genes per se in foam cell formation from monocytes is controversial. Multiple lines of evidence indicated that $C D 36$ and ACAT pave the way for the formation of foam cells through enhancing the capability of the cells to uptake platelets/ox-LDL and cholesterol esterification, respectively $[22,23]$. On the other hand, increased expression levels of $S R B, L X R-\alpha$, and $A B C A 1$ were also reported to be associated with the cholesterol efflux from macrophage foam cells $[24,25,26]$. Other studies also showed that the gene expression of proteins such as CD36, ACAT1, LXR- $\alpha$, and $A B C A 1$ are increased during macrophage-derived foam cell formation $[22,23,31,32]$. Tsukamoto et al. [33] suggested a fundamental role for $C D 36$ as well as $S R B$, but not $S R A$, in the formation of foam cells during ox-LDL treatment of THP-1 cells [33]. Of particular interest, co-culture of monocytes with the platelets of CAD patients resulted in a superior upregulation of CD36 and SRB mRNA expression as compared with the results of co-culture using platelets of healthy volunteers.

\section{Conclusion}

Using an in vitro co-culture of monocytes and platelets, our study indicates that platelets from CAD patients could provoke monocyte differentiation into macrophages with an M2 phenotype, which in turn may participate in an atheroprotective process.

\section{Acknowledgments}

We would like to acknowledge the Deputy of Research of the School of Allied Medical Sciences, Department of Cardiology, and the HSC Laboratory of Taleghani Hospital for support and the provision of research facilities.

\section{Ethics}

Ethics Committee Approval: The Ethics Committee of Shahid Beheshti University of Medical Sciences, approval number IR.SBMU.RETECH.REC.1396.717.

\section{Authorship Contributions}

Concept: M.H.; Design: M.H., M.M.; Selection of Patients: M.E.G.; Laboratory Practices (Cell Culture/Real Time/Flow Cytometry): M.M., M.H.M., M.E.G., E.S.S.; Collection of Data: M.M.; Analysis of Data: M.M.; Literature Search: M.H., M.M.; Writing: M.M., D.B., M.H.

Conflict of Interest: The authors of this paper have no conflicts of interest, including specific financial interests, relationships, and/or affiliations relevant to the subject matter or materials included.

\section{References}

1. Galkina $E$, Ley $K$. Immune and inflammatory mechanisms of atherosclerosis. Ann Rev Immunol 2009;27:165-197.

2. Mekaj YH. The roles of platelets in inflammation, immunity, wound healing and malignancy. Int J Clin Exp Med 2016;9:5347-5358.

3. Ghoshal K, Bhattacharyya M. Overview of platelet physiology: its hemostatic and nonhemostatic role in disease pathogenesis. ScientificWorldJournal 2014;2014:781857.

4. Heijnen HF, Debili N, Vainchencker W, Breton-Gorius J, Geuze HJ, Sixma JJ. Multivesicular bodies are an intermediate stage in the formation of platelet $\alpha$-granules. Blood 1998;91:2313-2325.

5. Golebiewska EM, Poole AW. Platelet secretion: from haemostasis to wound healing and beyond. Blood Rev 2015;29:153-162.

6. Gleissner CA, Shaked I, Little KM, Ley K. CXC chemokine ligand 4 induces a unique transcriptome in monocyte-derived macrophages. J Immunol 2010;184:4810-4818.

7. Aukrust $P$, Halvorsen B, Yndestad A, Ueland T, Øie E, Otterdal K, Gullestad L, Damås JK. Chemokines and cardiovascular risk. Arterioscler Thromb Vasc Biol 2008;28:1909-1919.

8. Stellos K, Langer H, Daub K, Schoenberger T, Gauss A, Geisler T, Bigalke B, Mueller I, Schumm M, Schaefer I, Seizer P, Kraemer BF, Siegel-Axel D, May $A E$, Lindemann $S$, Gawaz M. Platelet-derived stromal cell-derived factor-1 regulates adhesion and promotes differentiation of human CD34+ cells to endothelial progenitor cells. Circulation 2008;117:206215.

9. Stellos K, Seizer P, Bigalke B, Daub K, Geisler T, Gawaz M. Platelet aggregatesinduced human CD34+ progenitor cell proliferation and differentiation to macrophages and foam cells is mediated by stromal cell derived factor 1 in vitro. Semin Thromb Hemost 2010;36:139-145.

10. Stellos K, Bigalke B, Langer H, Geisler T, Schad A, Kögel A, Pfaff F, Stakos D, Seizer $P$, Müller I, Htun $P$, Lindemann $S$, Gawaz M. Expression of stromalcell-derived factor-1 on circulating platelets is increased in patients with acute coronary syndrome and correlates with the number of CD34+ progenitor cells. Eur Heart J 2009;30:584-593.

11. Rath $D$, Chatterjee $M$, Borst 0 , Müller $K$, Stellos $K$, Mack AF, Bongartz $A$, Bigalke B, Langer H, Schwab M, Gawaz M, Geisler T. Expression of stromal cell-derived factor- 1 receptors CXCR4 and CXCR7 on circulating platelets of patients with acute coronary syndrome and association with left ventricular functional recovery. Eur Heart J 2013;35:386-394.

12. Abbott JD, Huang Y, Liu D, Hickey R, Krause DS, Giordano FJ. Stromal cellderived factor- $1 \alpha$ plays a critical role in stem cell recruitment to the heart after myocardial infarction but is not sufficient to induce homing in the absence of injury. Circulation 2004;110:3300-3305.

13. Geisler T, Fekecs L, Wurster T, Chiribiri A, Schuster A, Nagel E, Miller S, Gawaz M, Stellos K, Bigalke B. Association of platelet-SDF-1 with hemodynamic function and infarct size using cardiac MR in patients with AMI. Eur J Radiol 2012;81:486-490.

14. Schrottmaier WC, Kral JB, Badrnya S, Assinger A. Aspirin and P2Y12 inhibitors in platelet-mediated activation of neutrophils and monocytes. Thromb Haemost 2015;114:478-489.

15. Chatterjee $M$, von Ungern-Sternberg $S N$, Seizer $P$, Schlegel $F$, Büttcher $M$, Sindhu NA, Müller S, Mack A, Gawaz M. Platelet-derived CXCL12 regulates monocyte function, survival, differentiation into macrophages and foam cells through differential involvement of CXCR4-CXCR7. Cell Death Dis 2015;6:e1989.

16. Murray PJ, Wynn TA. Obstacles and opportunities for understanding macrophage polarization. J Leukoc Biol 2011;89:557-563. 
17. Wolfs IM, Donners MM, de Winther MP. Differentiation factors and cytokines in the atherosclerotic plaque micro-environment as a trigger for macrophage polarisation. Thromb Haemost 2011;105:763-771.

18. Li W, Katz BP, Spinola SM. Haemophilus ducreyi-induced IL-10 promotes a mixed $\mathrm{M} 1$ and $\mathrm{M} 2$ activation program in human macrophages. Infect Immun 2012;80:4426-4434.

19. Khramtsova G, Liao C, Khramtsov A, Li S, Gong C, Huo D, Nanda R. The M2/ alternatively activated macrophage phenotype correlates with aggressive histopathologic features and poor clinical outcome in early stage breast cancer. In: Thirty-Second Annual CTRC-AACR San Antonio Breast Cancer Symposium, Abstracts, 2009.

20. Pulford $K$, Micklem $K$, McCarthy $S$, Cordell J, Jones M, Mason DY. A monocyte/macrophage antigen recognized by the four antibodies $\mathrm{GHI} / 61$, Ber-MAC3, Ki-M8 and SM4. Immunology 1992;75:588-595.

21. Moestrup SK, Møller HJ. CD163: A regulated hemoglobin scavenger receptor with a role in the anti-inflammatory response. Ann Med 2004;36:347-354.

22. Yao $S$, Miao $C$, Tian $H$, Sang $H$, Yang $N$, Jiao $P$, Han J, Zong $C$, Qin $S$. Endoplasmic reticulum stress promotes macrophage-derived foam cell formation by up-regulating cluster of differentiation 36 (CD36) expression. J Biol Chem 2014;289:4032-4042.

23. Yang L, Yang JB, Chen J, Yu GY, Zhou P, Lei L, Wang ZZ, Cy Chang C, Yang XY, Chang TY, Li BL. Enhancement of human ACAT1 gene expression to promote the macrophage-derived foam cell formation by dexamethasone. Cell Res 2004;14:315-323.

24. Yvan-Charvet $L$, Wang $N$, Tall AR. Role of HDL, $A B C A 1$, and $A B C G 1$ transporters in cholesterol efflux and immune responses. Arterioscler Thromb Vasc Biol 2010;30:139-143.
25. Hamidpour M, Bashash D, Nehzati P, Abbasalizadeh M, Hamidpour R. The expression of hSR-B1 receptor on platelets of patients with coronary artery disease (CAD). Clin Hemorheol Microcirc 2019;71:9-15.

26. Chawla A, Boisvert WA, Lee $C H$, Laffitte BA, Barak Y, Joseph SB, Liao D, Nagy L, Edwards PA, Curtiss LK, Evans RM, Tontonoz P. A PPAR $\gamma$-LXR-ABCA1 pathway in macrophages is involved in cholesterol efflux and atherogenesis. Mol Cell 2001;7:161-171.

27. Lievens $D$, von Hundelshausen P. Platelets in atherosclerosis. Thromb Haemost 2011;105:827-838.

28. Chatterjee M, Gawaz M. Platelet-derived CXCL 12 (SDF-1 $\alpha$ ): basic mechanisms and clinical implications. J Thromb Haemost 2013;11:19541967.

29. Ratcliffe NR, Kennedy SM, Peter PM. Immunocytochemical detection of Fcy receptors in human atherosclerotic lesions. Immunol Lett 2001;77:169-174.

30. Buchacher T, Ohradanova-Repic A, Stockinger H, Fischer MB, Weber V. M2 polarization of human macrophages favors survival of the intracellular pathogen Chlamydia pneumoniae. PLoS One 2015;10:e0143593.

31. Langmann T, Klucken J, Reil M, Liebisch G, Luciani MF, Chimini G, Kaminski WE, Schmitz G. Molecular cloning of the human ATP-binding cassette transporter 1 ( $\mathrm{hABC} 1$ ): evidence for sterol-dependent regulation in macrophages. Biochem Biophys Res Commun 1999;257:29-33.

32. Shiffman D, Mikita T, Tai JT, Wade DP, Porter JG, Seilhamer JJ, Somogyi $\mathrm{R}$, Liang S, Lawn RM. Large scale gene expression analysis of cholesterolloaded macrophages. J Biol Chem 2000;275:37324-37332.

33. Tsukamoto K, Kinoshita M, Kojima K, Mikuni Y, Kudo M, Mori M, Fujita M, Horie E, Shimazu N, Teramoto T. Synergically increased expression of CD36, CLA-1 and CD68, but not of SR-A and LOX-1, with the progression to foam cells from macrophages. J Atheroscler Thromb 2002;9:57-64. 